\title{
Recovery of Agricultural Areas Affected by Traditional Gold Mining: Sustainable Food Supply Stability
}

\author{
Golar Golar ${ }^{*}$, Muhammad Basir-Cyio ${ }^{2}$, Isrun Isrun², Rahmat Bakri ${ }^{3}$, Muhammad Rusydi ${ }^{4}$, Bohari Bohari ${ }^{5}$, \\ Muhammad Fardhal Pratama \\ ${ }^{1}$ Faculty of Forestry, Universitas Tadulako, Palu 94119, Indonesia \\ ${ }^{2}$ Faculty of Agriculture, Universitas Tadulako, Palu 94119, Indonesia \\ ${ }^{3}$ Faculty of Law, Universitas Tadulako, Palu 94119, Indonesia \\ ${ }^{4}$ Faculty of Math and Science, Universitas Tadulako, Palu 94119, Indonesia \\ ${ }^{5}$ Department of Nutrition, Faculty of Medicine, Universitas Sultan Ageng Tirtayasa, City of Serang 42118, Indonesia
}

Corresponding Author Email: golar.tadulako@gmail.com

https://doi.org/10.18280/ijdne.160207

Received: 26 October 2020

Accepted: 22 February 2021

\section{Keywords:}

recovery model, an agricultural area, goldmine, land reclamation, rehabilitation

\begin{abstract}
This study aims to analyze the recovery of the agricultural area's function affected by the Poboya traditional gold mining in supporting the stability of sustainable food supply. We began the research by examining the existing mining land conditions through spatial analysis (land cover and land use changes from 2010 to 2019). Apart from that, it also analyzed the land's health was through the soil's physical and chemical properties, especially mercury. The observation proved that changes in the land's cover and uses lead to decreased land quality and degradation. The existing condition showed heavy metals, particularly mercury, mostly polluted agricultural land in the mining area. The model design produced by this study may 1) emphasize land arrangement; 2) revegetation design with forestry, plantation, and food crops; 3) domesticated plant; and 4) environmental monitoring, concerning monitoring of soil quality, monitoring of erosion and sedimentation, water quality, acid mine drainage, successful revegetation, and others. These four aspects expect to help suppress the rate of land degradation in agriculture located in ex-mining areas and reduce forest destruction in the Grand Forest Park area.
\end{abstract}

\section{INTRODUCTION}

Palu is one of the cities located in Central SulawesiIndonesia, which has considerable potential for gold mining resources. The exact location is in Poboya, with a mine area of 49,460 ha. Estimated reserves are 1.5 million oz $\mathrm{Au}$ (USD 300/oz Au), 1.5 million oz Ag (USD 5/oz Ag), with an estimated production of $150,000 \mathrm{oz} \mathrm{Au} /$ Year [1]. More than $90 \%$ of gold mining activities in Central Sulawesi are managed traditionally and are categorized as illegal. Environmentally friendly principles are not considered, including mercury [2, 3]. The use of mercury in traditional mining activities making it easier for them to mine gold. Many can impact public health [4], environmental degradation, which in the long term can reduce the productivity of land [5].

Poboya is one of the horticultural crop-producing areas in Palu City. However, since traditional gold mining activities, the agricultural area in Poboya has experienced severe degradation and land conversion. It is resulting in a decrease in the food supply in Palu City. Previous research in Poboya found a change in agricultural land's function into a gold mining area with a very high mercury pollution level and threatening Palu residents' health on a large scale $[6,7]$.

Protection and management of the environment need to carry out thoughtfully and consistently to create environmental quality for human life and other living creatures [8-10]. Some efforts should make to find the right handling solution without causing social, economic, and ecological impacts to the community [10-12]. One of them is to recover land affected by the mine [13-15]. But unfortunately, there has been no effort to recover the function of agricultural land around the illegal gold mining area in Poboya. The existing land condition shows the land cover that has been cleared. Many traditional exmining lands cannot be used for the community's productive activities, especially in the agricultural sector.

Another emerging issue is the threat to forest areas' conservation in the Grand Forest Park (TAHURA). One of them is the pressure on forest areas due to land use activities carried out by the community. It is the cause of compensation for their land affected by mining activities and covid 19 diseases [16, 17]. It is crucial because most people in this region rely heavily on arable land, both in the village and forest areas $[6,18]$. It will have a broad impact on land and forest land if not resolved immediately.

It is required recovery efforts to restore the function of the affected agricultural areas in ex-goldmine. This study analyzes the recovery model for the operation of farming areas affected by the goldmine to support sustainable food supply stability and decreasing forest degradation.

\section{METHOD}

The recovery of the agricultural area function is carried out by preparing a land recovery model. Focus on farming areas affected by the goldmine in Poboya (Figure 1). The recovery 
location chosen was land that formerly illegal mining activity, which was once productive agricultural land.

The data analyzed consisted of high-resolution satellite imagery in 2010 and 2019 using ArcGIS 10.8 with serial number: EVA941292912). Analyzed the land cover and landuse changes descriptively by combining data on land ownership, land use in the TAHURA area, and several existing conditions obtained from field surveys (Figure 2). It is also combined with soil's structure, texture, and metal content at the research location.

The analysis results were then used as primary data in developing a recovery model for the ex-Poboya mine land. The model design consists of recovery land use, forestry plant revegetation, plantations, and food crops, improving the quality of planting media, cover crop planting, maintenance, and environmental monitoring. The resulting model design is made in the form of a land-use distribution map.

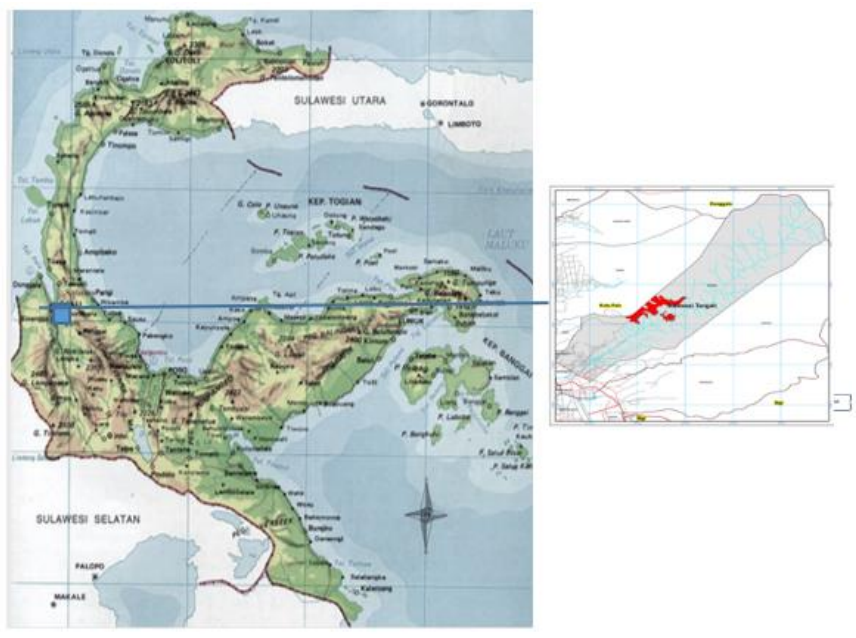

Figure 1. Research location

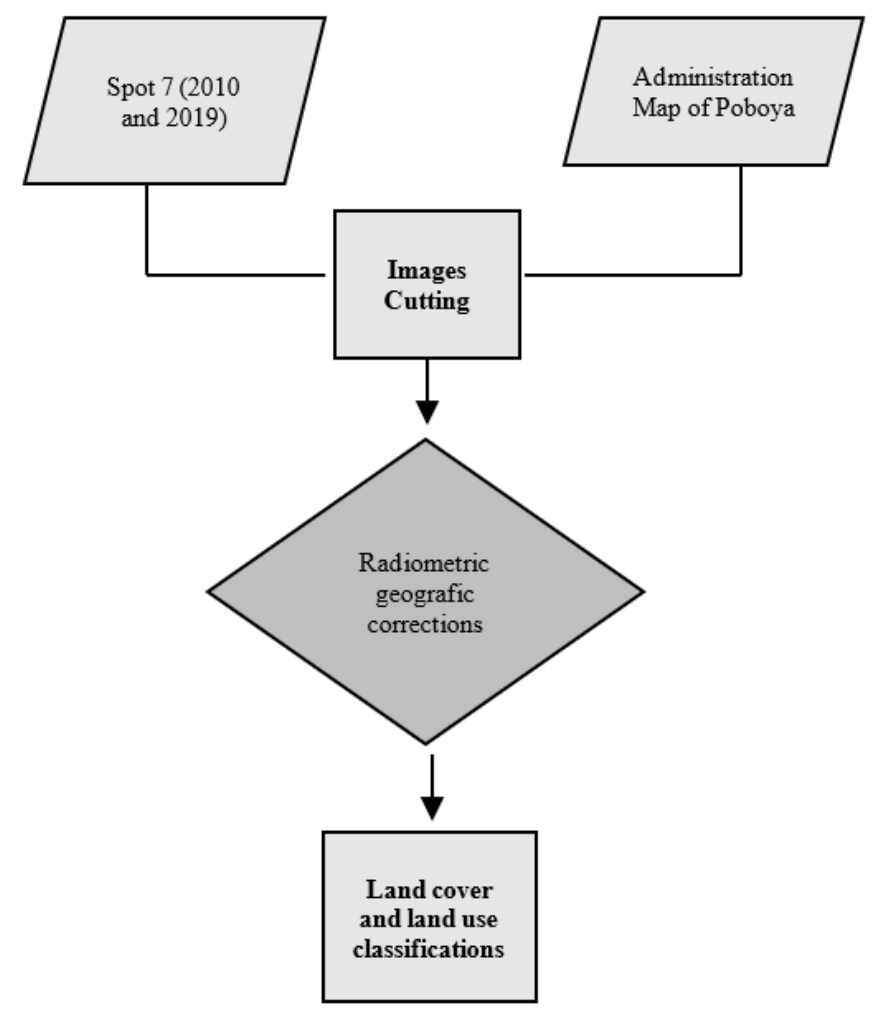

Figure 2. Land cover and land-use change analysis

\section{RESULTS \& DISCUSSIONS}

\subsection{Land cover and land use changes}

Information on land's cover and land use provide up-to-date information regarding land use dynamics /and the amount of pressure on the area $[19,20]$. Through this information, we can perform a series of analyzes and design a management model following its designation, including land recovery efforts (see Figure 3).

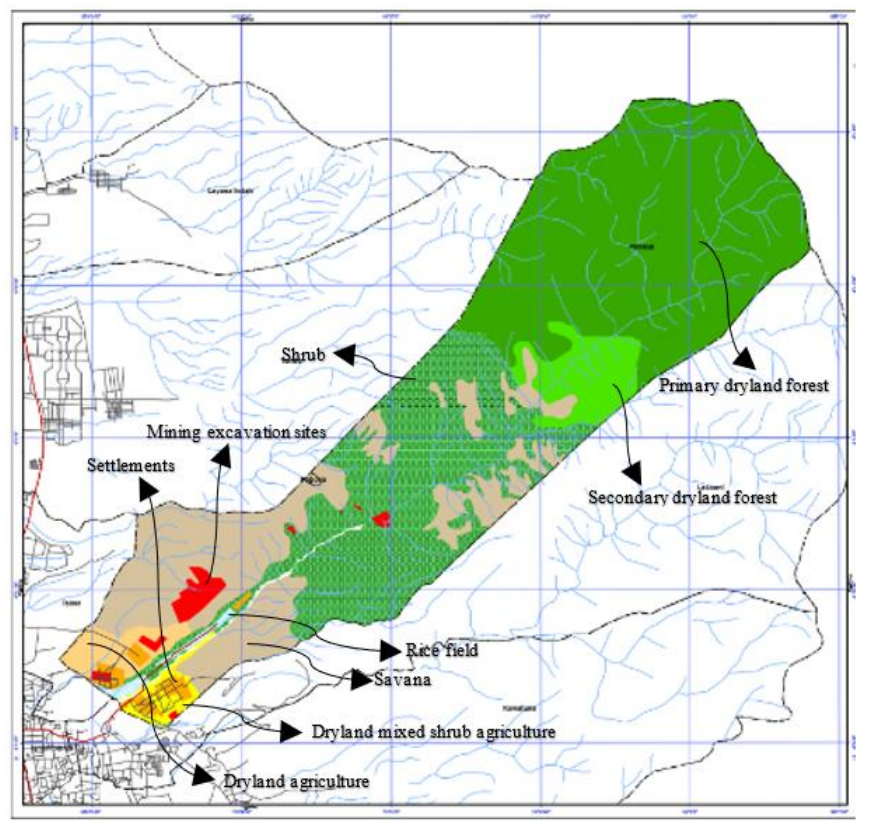

(a) Land cover map (2010)

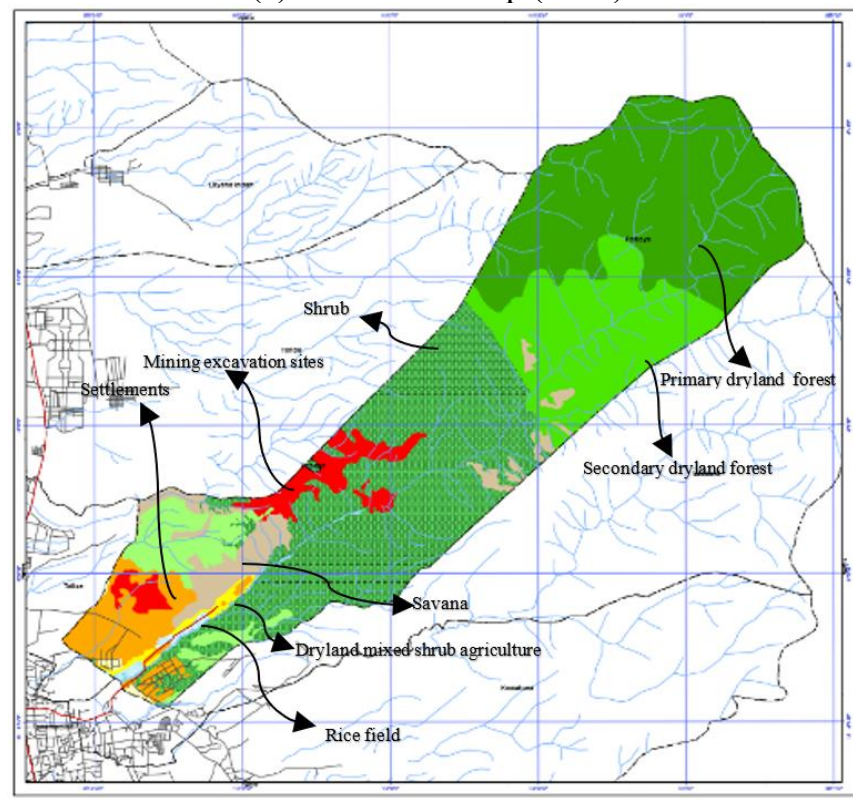

(b) Land cover map (2019)

Figure 3. Comparison of the Land cover in Poboya

The land cover results found 9 (nine) types of land cover, including primary dryland forest, secondary dryland forest, mining excavation sites, settlements, dryland agriculture, and dryland mixed shrub agriculture, savanna, rice fields, and shrubs. The area of each land cover present in Table 1.

Table 1 shows the change in land cover, both increasing and decreasing from 2010 to 2019. Primary dryland forest had been reduced by an area of 532.45 ha, where the land cover of 
primary dryland forest had been converted into secondary dryland forest covering 531.91 ha and shrubs of 0.54 ha. In 2010 , initially, the secondary dryland forest area was 267.91, then in 2019 , it changed to 263.03 ha. That indicates that the secondary dryland forest has changed in a land cover of 4.88 ha. The land cover of secondary dryland forest changed to savanna by 3.18 ha and shrubs of 1.70 ha.

For the period 2010 to 2019, experienced a change in land cover of 66.19 ha. The mining area was excavated to a 7.24 ha plantation forest, 31.34 ha settlements, 1.62 ha dryland farming, 1.73 ha savanna, and 24.26 ha shrubs. Meanwhile, the land cover of rice fields from 2010 to 2019 had changed, involving settlements covering an area of $3.58 \mathrm{ha}$, dryland agriculture covering an area of $0.38 \mathrm{ha}$, and dryland farming mixed with shrubs covering 13.19 ha, and shrubs of 0.06 ha.

The cover of shrubland has also changed outside from 2010 to 2019 , covering 304.91 ha. Land cover changes that occur in shrubland to dryland forest (175.81 ha), plantation forest ( 0.31 ha), mining excavation sites (78.48 ha), the residential land (7.63 ha), dryland farming mixed with shrubs (19.57 ha), savanna (17.80 ha) and rice fields (5.31 ha).

Table 1. Land cover changes in period 2010 and 2019

\begin{tabular}{|c|c|c|}
\hline Land Cover 2010 & Land Cover 2019 & Total \\
\hline \multirow{3}{*}{ Primary Dryland Forest } & Primary Dryland Forest & $\begin{array}{c}1561.7 \\
0\end{array}$ \\
\hline & $\begin{array}{c}\text { Secondary Dryland } \\
\text { Forest }\end{array}$ & 531.91 \\
\hline & Shrubs & 0.54 \\
\hline \multicolumn{2}{|c|}{ Total Primary Dryland Forest } & $\begin{array}{l}2094.1 \\
6\end{array}$ \\
\hline \multirow{3}{*}{$\begin{array}{c}\text { Secondary Dryland } \\
\text { Forest }\end{array}$} & $\begin{array}{c}\text { Secondary Dryland } \\
\text { Forest }\end{array}$ & 263.03 \\
\hline & Savanna & 3.18 \\
\hline & Shrubs & 1.70 \\
\hline \multicolumn{2}{|c|}{ Total Secondary Dryland Forest } & 267.91 \\
\hline \multirow{5}{*}{$\begin{array}{c}\text { Mining Excavation } \\
\text { Location }\end{array}$} & Plantation Forest & 7.24 \\
\hline & $\begin{array}{l}\text { Mine Excavation } \\
\text { Location }\end{array}$ & 8.52 \\
\hline & Settlements & 31.34 \\
\hline & Dryland farming & 1.62 \\
\hline & Savanna & 1.73 \\
\hline & Shrubs & 24.26 \\
\hline \multicolumn{2}{|c|}{ Total Mining Excavation Locations } & 74.70 \\
\hline Settlements & Settlements & 64.05 \\
\hline \multicolumn{2}{|c|}{ Total Settlements } & 64.05 \\
\hline \multirow{4}{*}{ Dryland Farming } & $\begin{array}{c}\text { Plantation Forest } \\
\text { Open field }\end{array}$ & $\begin{array}{c}1.11 \\
1.06 \\
35.41\end{array}$ \\
\hline & $\begin{array}{c}\text { Dry Land Mixed Shrub } \\
\text { Farm }\end{array}$ & 0.06 \\
\hline & Savanna & 57.51 \\
\hline & Shrubs & 27.86 \\
\hline \multicolumn{2}{|c|}{ Total Dryland Farming } & 123.00 \\
\hline \multirow{6}{*}{$\begin{array}{c}\text { Dryland Mixed Shrub } \\
\text { Farming }\end{array}$} & Plantation Forest & 1.42 \\
\hline & Settlements & 14.80 \\
\hline & Dryland farming & 5.75 \\
\hline & $\begin{array}{c}\text { Dry Land Mixed Shrub } \\
\text { Farm }\end{array}$ & 1.63 \\
\hline & Rice fields & 2.70 \\
\hline & Shrubs & 35.35 \\
\hline \multicolumn{2}{|c|}{ Total Dryland Mixed Shrub Farming } & 61.65 \\
\hline \multirow{2}{*}{ Savanna } & $\begin{array}{c}\text { Secondary Dryland } \\
\text { Forest }\end{array}$ & 32.39 \\
\hline & $\begin{array}{l}\text { Plantation Forest } \\
\text { Open field }\end{array}$ & $\begin{array}{c}216.86 \\
0.05\end{array}$ \\
\hline
\end{tabular}

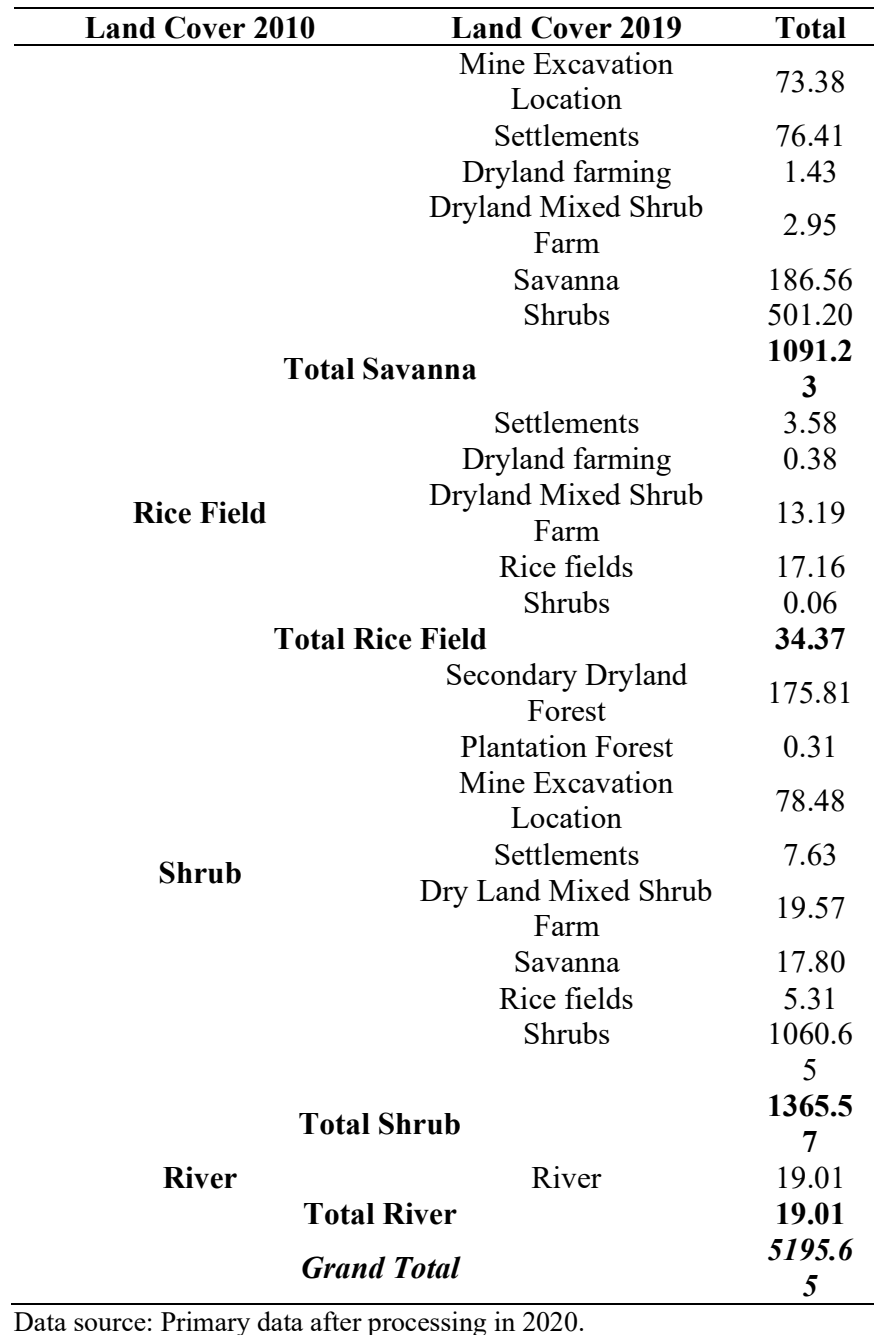

\subsection{Existing conditions}

Spatial analysis showed that the mine area (see Figure 4) was $160.38 \mathrm{Ha}$, spread over the Poboya area. Mining activities in Poboya create externalities for the environment. Mining activities using drum machines by the miners also produce waste such as liquid waste, solid waste, and waste in particulates in the air. Mining waste is hazardous and can cause environmental damage due to irregular waste disposal [21]. Liquid waste is disposed of in ponds near houses and community wells, resulting in soil damage to crack the ground's water [22].

Land damage at the gold mining location is categorized as severe damage and causes physical environmental impacts such as land degradation. Land degradation involving the loss of nutrients needed by plant growth, reduced surface water discharge, high vehicle traffic, creates easily damaged roads and air pollution. Soil health is also an essential factor, primarily if land restoration is used for planting food crops. Not all ex-mining land is dangerous from a food safety aspect. Some of them need to be considered, mostly if a geochemical element of the extraction method of mining materials produces or uses harmful compounds for the environment (Figure 5).

The real impact on the growth area and the surrounding area is erosion and sedimentation [18], increasing heavy metal content in the soil that can enter the aquatic environment by decreasing the quantity and quality of water [23]. It causes biodiversity loss, changing landscapes, and health disturbances in communities around the Poboya mining areas $[24,25]$. 


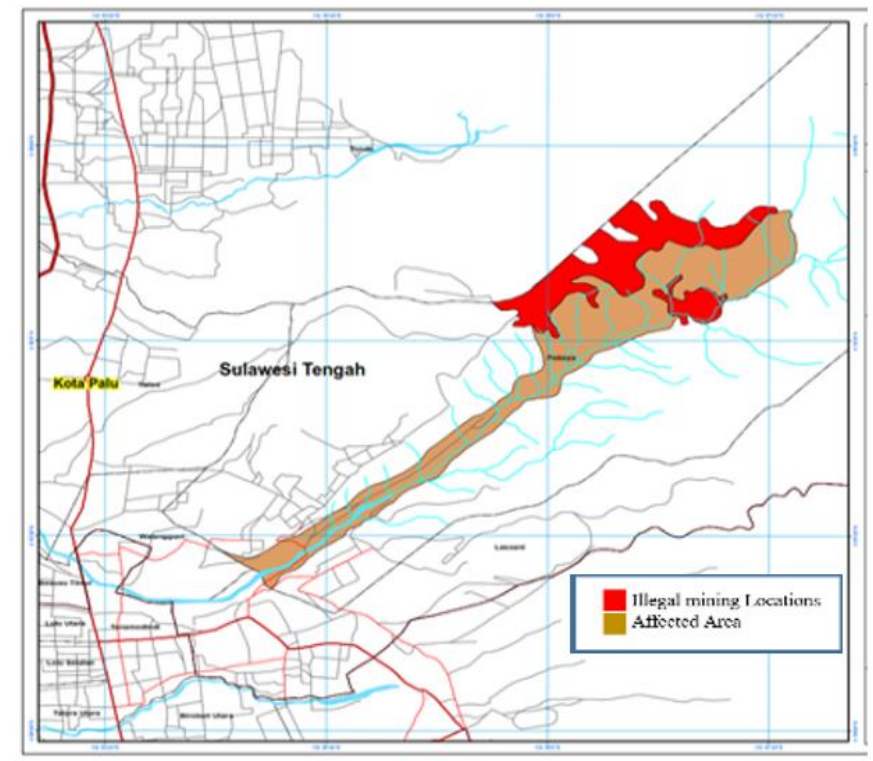

Figure 4. Mine-affected areas (2019)
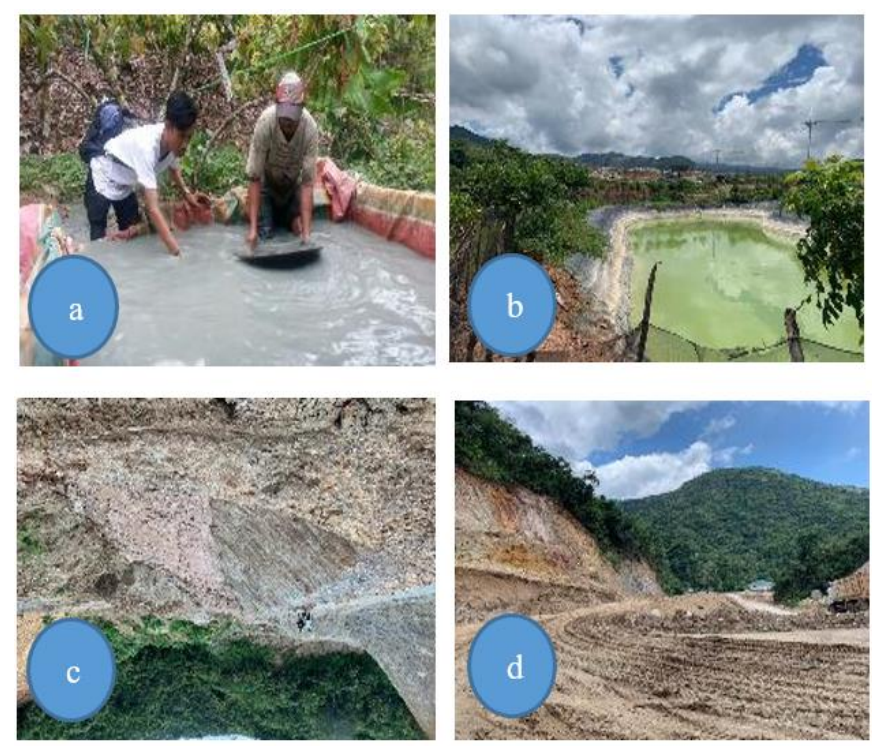

Figure 5. (a) The process of separating gold from other materials; (b) mining waste storage location; (c) affected river; and (d) soil damage at the transport site

Toxic metal contamination into agricultural soil causes stress on crops. Plant stress caused by toxic metals is three times greater than that caused by pesticides. In general, these toxic metals are trace elements that occur both naturally and from illegal mining activities [7]. If these heavy metals' concentration is higher, it can cause environmental damage for a long time [26]. The negative impact of heavy metals on soil and plants decreases organisms' activity and ground fertility $[26,27]$. As a result, the amount of production has also reduced. It is triggered the community to look for alternative substitutes by infringing on the TAHURA [16].

The soil analysis results in the soil's physical and chemical aspects, which are textured with sandy loam and loam. Soil permeability is relatively slow to fast. According to the Soil Taxonomy classification, the soil type in the study area is Entisols, which do not have a cambic, argillic, candic, or natric horizon to a depth of $100 \mathrm{~cm}$ and occur in alluvial plains.

Previous research has described soil conditions, including plants in the Poboya area, contaminated with heavy metal mercury from soil health. The mercury $(\mathrm{Hg})$ content of the soil in open land has exceeded the critical threshold of 1.26-8.19 ppm [18]. It shows the mercury content in the ground in this area is classified as high by the quality standard. It is caused by the contamination of processed gold waste used by the Poboya gold miners [6, 28].

The soil's Hg content ranged from $0.85 \mathrm{ppm}-2.62 \mathrm{ppm}$ in food plants and secondary crops. In coconut plantations and mixed gardens, it was $0.57 \mathrm{ppm}-0.76 \mathrm{ppm}$. The highest and critical $\mathrm{Hg}$ concentration was measured in the goldmine processing area, namely $84.15 \mathrm{ppm}-575.16 \mathrm{ppm}$. The high content of mercury $(\mathrm{Hg})$ in the goldmine processing area is due to mercury at the processing time, reaching $500 \mathrm{cc}$ per drum per one-time processing [18]. Thus, land contaminated with waste or tailings containing mercury is much higher in mercury content, impacting the surrounding land, either directly or indirectly.

The closer the distance from the processing location, the higher the mercury concentration compared to places far from the processing location. According to the effects of soil testing, the research results show that the distribution of mercury concentrations in the study area shows that most of the land around Poboya, including TAHURA, is classified as unhealthy. Includes plants on it that have been contaminated $[6,27]$.

\subsection{The potential forest degradation in TAHURA}

TAHURA Palu is one of the conservation areas confirmed by KepMenHut No. 24/Kpts-II/1999, with an area of 7,128 ha or $0.186 \%$ of the total forest area of Central Sulawesi $(3,833,330 \mathrm{ha})$ or about $1,174 \%$ of the conservation area $(607,100 \mathrm{ha})$ in Central Sulawesi. Since designated as a nature conservation area, TAHURA many face a variety of obstacles in its management. A land invasion of forest areas for use outside the function of unstoppable forests to utilize land in this area. TAHURA has been affected by gold mining by mining communities, especially in Poboya and surrounding areas.

The insistence on the need for agricultural business land encourages the community to creep into the TAHURA Area. Encroachment activities existed before illegal gold mining activities existed. But the trend continues to grow today. The main reason is the insistence on agricultural land's need due to their land affected by gold mining activities. They do not understand that the location is a conservation area, where they cannot utilize the ground for some social and economic purpose.

Forest encroachment activities that take place in the TAHURA region have the potential to damage forest areas. A potential form of damage is the formation of critical lands that have to threaten erosion $[12,13,19]$. Besides, the conservation area's main functions will be disrupted, so it must be completed immediately [24, 29].

Potential tenurial conflicts will be formed significantly when land demand increases, while land-use opportunities in forest areas are increasingly limited. This situation is found in many other places, where the need for arable land is one of the causes of social conflict in conservation areas [27-29]. Potential social disputes in the TAHURA region need to get the same attention as other potential conflicts. The impact can be extensive and take a lot of time and resources to complete. Therefore, before this situation occurred, anticipative measures of a multi-party (collaborative) [30-35]. 
Agroforestry can be used as a collaborative approach in rehabilitating forest land in TAHURA [36]. In Poboya, there are several traditional agroforestry systems, such as Pekarangan (Homegarden) and Tumpangsari (Taungnya). That is potential to integrate into forest development programs (Figure 6).

Several government programs can be integrated, including social forestry programs and environmental partnerships [3539]. Hopefully, through this program, community participation can be increased [31].

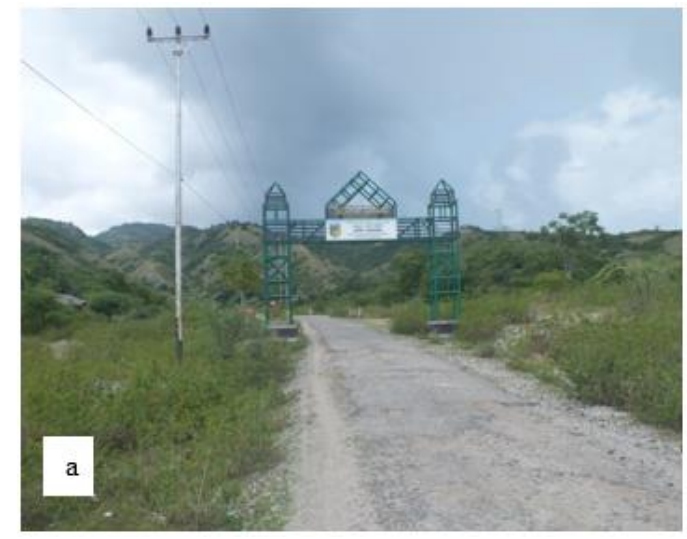

(a) Location of TAHURA Palu

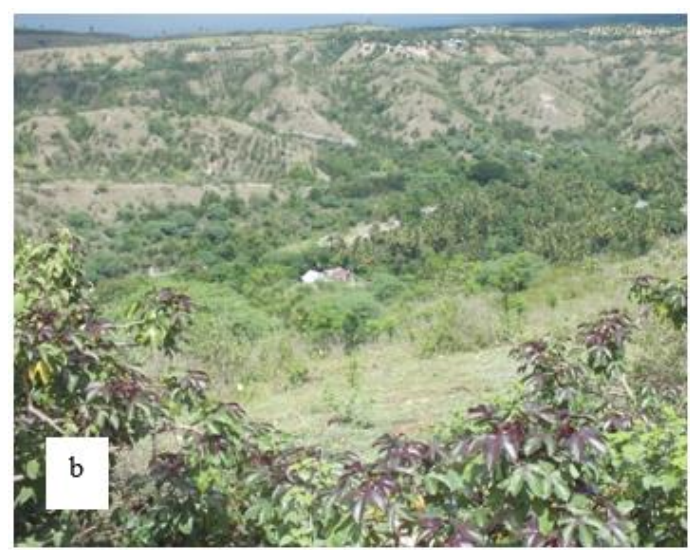

(b) Conditions of the area around TAHURA

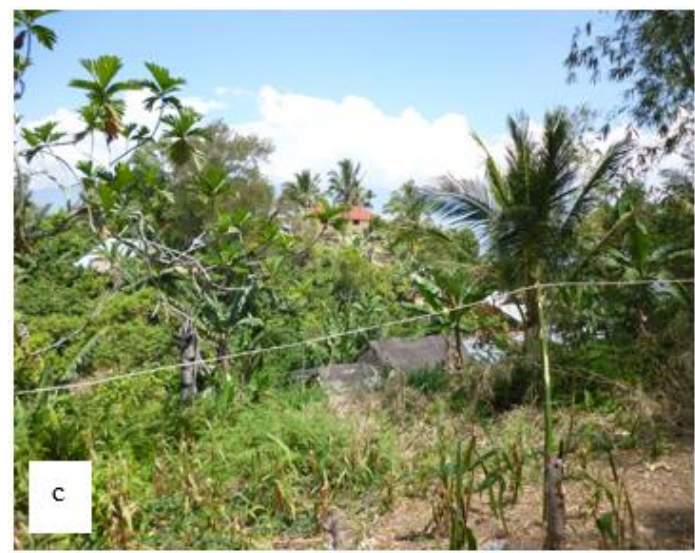

(c) The traditional Agroforestry System Near TAHURA

Figure 6. Existing conditions in TAHURA

\subsection{Model design}

The model is based on preliminary analysis results related to land cover, land-use change, existing conditions, and forest degradation. This study has determined 4 (four) principal components of the model of land recovery: land arrangement, soil improvement, revegetation, and maintenance (Figure 7).

Based on the land cover analysis, there are still potential agricultural cultivation areas. It requires action and appropriates reclamation and rehabilitation technology input beforehand for optimizing plant growth [25]. The reclamation of disturbed lands involves several steps [40]: (i) land characteristics, (ii) engineering and reclamation planning, (iii) material management, (iv) topographic reconstruction, (v) restoration of topsoil or a suitable replacement, (vi) land surface manipulation, (vii) soil amendments, (viii) revegetation, (ix) irrigation (if required), and (x) maintenance and monitoring.

The recovery model is a combination of land reclamation and rehabilitation. Reclamation aims to restore the land to its original state [40]. These activities include leveling the soil surface, returning topsoil (actual tillage), and planting pioneer plants. Land rehabilitation improved fertility and the soil's physical properties to be used as agricultural land [25]. Land rehabilitation is also intended for forest land in TAHURA that has been degraded.

Utilizing ex-mining land requires high input to restore soil fertility which takes a long time, mostly if it relies on natural processes. One of the ways is to change the soil. It has an adequate support capacity for plant growth to restore the texture, structure, and organic matter to the right conditions. All the plant's cultivated benefit farmers, and the environment becomes even better $[25,41]$. To overcome, that is necessary to reclaim ex-mining land by revegetating or supplying organic matter [41, 42].

Other studies have shown action is needed to remove unresolved soil density through planting reclamation vegetation, particularly in ex-mining areas [41]. The application of agricultural lime and phosphorus fertilizers must be carried out on ex-mining land, which will be used for agricultural food crops [43]. Revegetation activities can also adopt an agroforestry system [44]. Apart from being useful for increasing the number of plant species variations, this pattern also aims to increase community participation [45].

This pattern's implementation can be done collaboratively with the TAHURA management and ex-miners, universities, and non-governmental organizations. The location selection is prioritized for TAHURA lands that have been occupied or encroached by the community. The revegetation model can apply an active participatory pattern by involving ex-mining communities or communities whose land is affected by mining activities. Besides TAHURA, universities and local governments continue to facilitate and provide assistance to the community's maintenance process [33, 34].

Apart from plants, maintenance activities include maintaining the field's physical conditions (slopes, drainage channels, settling ponds). This activity requires active support from related technical agencies and local governments. The environmental monitoring model is carried out on an ongoing basis starting from the start of revegetation activities.

Affiliated textual agencies and universities carry out monitoring activities. Besides technical reasons, environmental monitoring requires accurate results and requires analysis at every stage of the monitoring. Therefore, the team that will work on this activity requires special qualifications.

Spatially, the design of the ex-mining land recovery model can be seen in Figure 8 . 


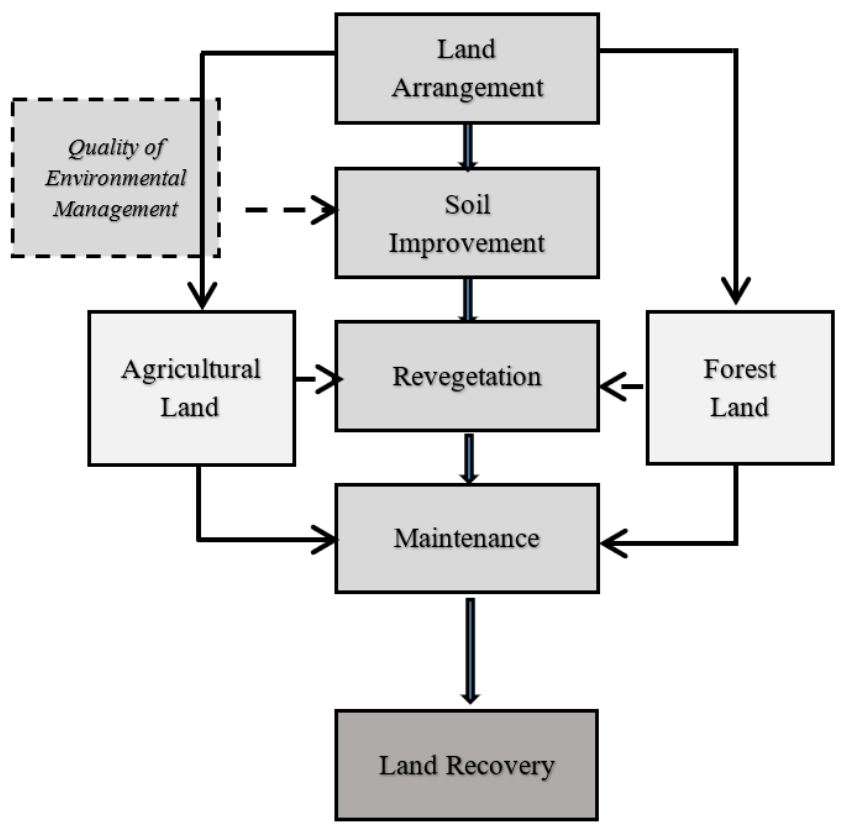

Figure 7. Recovery models design

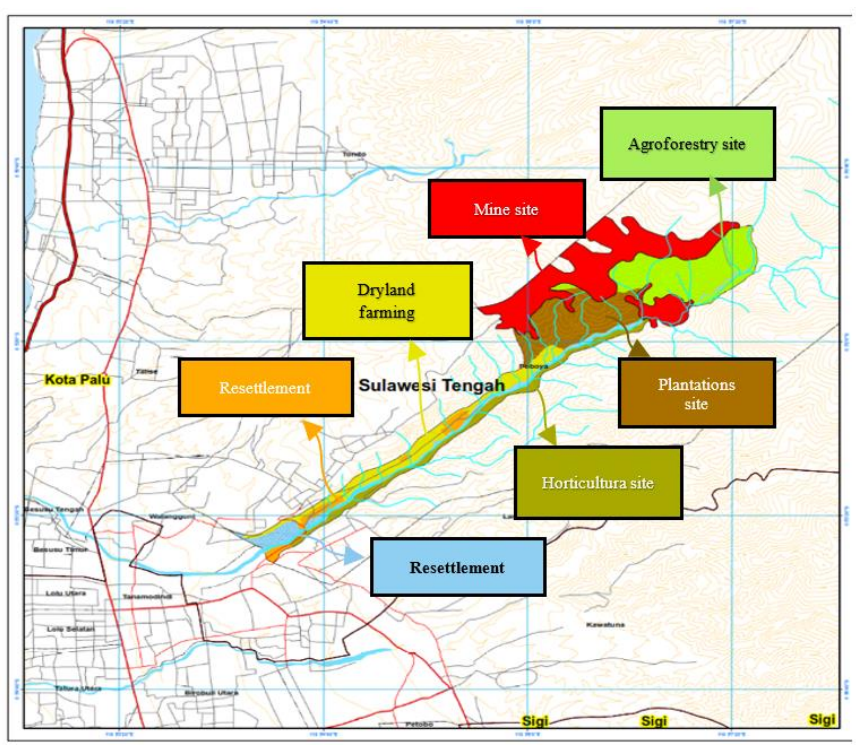

Figure 8. Spatial model of Poboya ex-mine land recovery

\section{CONCLUSION}

Land conditions in the ex-Poboya mining area require serious attention in handling. The research results prove that land cover changes and land-use lead to decreased quality and land degradation. The existing condition shows that agricultural land in the mining area is mostly polluted by heavy metals, especially by mercury, so it is necessary to recover the ground.

The model design produced by this study emphasizes land arrangement, forest rehabilitation, plantation, and food crops, plant pets, and environmental monitoring, concerning monitoring of soil quality, monitoring of erosion, water quality, acid mine drainage, revegetation, and others. These four aspects are expected to help reduce the rate of damage to land in agriculture in the ex-mining area and, at the same time, reduce the rate of forest destruction in the TAHURA.
Its success is mostly determined by the intensity of community participation and the parties' active role (support from specialized agencies, universities, and local governments). The recovery model can be applied if (1) commitment of various parties to jointly improve environmental conditions; (2) The full support of the government, in this case, the management of TAHURA and the local government, as well as the Environment and Forestry Ministry; (3) Active participation of the community, especially those directly affected by illegal mining activities.

However, this model still requires testing and validation at the field level to obtain an ideal model that can serve as a prototype for handling mine land recovery for community food security.

\section{ACKNOWLEDGMENT}

This research was conducted at the Directorate General of Higher Education's expense through a flagship Research scheme. We express our thanks to the Ministry of Education of the Republic of Indonesia and the Tadulako University Research Institute for all the facilities provided so that this research can be carried out well. We are also grateful for the help of the licensed ArcGIS 10.7 program from ESRI Indonesia.

\section{REFERENCES}

[1] Pemerintah Daerah Provinsi Sulawesi Tengah. (2019). Mining and Energy Sector. https://www.sultengprov.go.id/pagesc/9/sektorpertambangan-dan-energi, accessed Feb. 24, 2021.

[2] Hilson, G., Laing, T. (2017). Gold mining, indigenous land claims, and conflict in Guyana's hinterland. Journal of Rural Studies, 50: 172-182. https://doi.org/10.1016/j.jrurstud.2017.01.004

[3] Al Rawashdeh, R., Campbell, G., Titi, A. (2016). The socio-economic impacts of mining on local communities: The case of Jordan. Extr. Ind. Soc., 3(2): 494-507. https://doi.org/10.1016/j.exis.2016.02.001

[4] Lallier, L.E., Maes, F. (2016). Environmental impact assessment procedure for deep seabed mining in the area: Independent expert review and public participation. Mar. Policy, 70: 212-219. https://doi.org/10.1016/j.marpol.2016.03.007

[5] Bilici, E., Saygın, Y. (2017). Why do people (not) like me?: Mining opinion influencing factors from reviews. Expert Systems with Applications, 68: 185-195. https://doi.org/10.1016/j.eswa.2016.10.001

[6] Sari, M.M., Inoue, T., Matsumoto, Y., Yokota, K., Isrun, I. (2016). Assessing a mercury affected area from smallscale gold mining in Poboya, Central Sulawesi, Indonesia. Environment and Ecology Research, 4(4): 223-230.

[7] Nakazawa, K., Nagafuchi, O., Kawakami, T., Inoue, T., Yokota, K., Serikawa, Y., Cyio, B., Elvince, R. (2016). Human health risk assessment of mercury vapor around artisanal small-scale gold mining area, Palu city, Central Sulawesi, Indonesia. Ecotoxicology and Environmental Safety, 124: 155-162. https://doi.org/10.1016/j.ecoenv.2015.09.042

[8] Bray, D.B. (2015). Community forestry as a strategy for 
sustainable management. in working forests in the Neotropics, Columbia University Press, pp. 221-237.

[9] Hvenegaard, G.T., Carr, S., Clark, K., Dunn, P., Olexson, T. (2015). Promoting sustainable forest management among stakeholders in the prince albert model forest. Canada. Conserv. Soc., 13(1): 51-61. https://doi.org/10.4103/0972-4923.161222

[10] Khuc, Q.V., Tran, B.Q., Meyfroidt, P., Paschke, M.W. (2018). Drivers of deforestation and forest degradation in Vietnam: An exploratory analysis at the national level. Forest Policy and Economics, 90: 128-141. https://doi.org/10.1016/j.forpol.2018.02.004

[11] Shao, Y., Jiang, Q., Wang, C., Wang, M., Xiao, L., Qi, Y. (2020). Analysis of critical land degradation and development processes and their driving mechanism in the Heihe River Basin. Science of the Total Environment, 716: 137082 https://doi.org/10.1016/j.scitotenv.2020.137082

[12] Gunn, J.S., Ducey, M.J., Belair, E. (2019). Evaluating degradation in a North American temperate forest. Forest Ecology and Management, 432: 415-426. https://doi.org/10.1016/j.foreco.2018.09.046

[13] Koglo, Y.S., Gaiser, T., Agyare, W.A., Sogbedji, J.M., Kouami, K. (2019). Implications of some major humaninduced activities on forest cover using extended change matrix quantity and intensity analysis based on historical Landsat data from the Kloto District, Togo. Ecological Indicators, 96: 628-634 https://doi.org/10.1016/j.ecolind.2018.09.042

[14] Vélez, M.A., Robalino, J., Cardenas, J.C., Paz, A., Pacay, E. (2020). Is collective titling enough to protect forests? Evidence from Afro-descendant communities in the Colombian Pacific region. World Development, 128: 104837. https://doi.org/10.1016/j.worlddev.2019.104837

[15] Muhati, G.L., Olago, D., Olaka, L. (2018). Land use and land cover changes in a sub-humid Montane forest in an arid setting: A case study of the Marsabit forest reserve in northern Kenya. Global Ecology and Conservation, 16: e00512. https://doi.org/10.1016/j.gecco.2018.e00512

[16] Golar. (2019). Gold mining and its impact on agricultural land, public health, violation of the law: a study on poboya traditional mining, Palu, Indonesia. Indian $\mathrm{J}$. Public Health Res. Dev., 10(10): 924. https://doi.org/10.5958/0976-5506.2019.02939.5

[17] Golar, G., Malik, A., Muis, H., Herman, A., Nurudin, N., Lukman, L. (2020). The social-economic impact of COVID-19 pandemic: Implications for potential forest degradation. Heliyon, 6(10): e05354. https://doi.org/10.1016/j.heliyon.2020.e05354

[18] Mirdat, Y.S. Patádungan, I. (2013). The level of heavy metal of mercury $(\mathrm{Hg})$ in soil of agricultural area around Gold Mining in Poboya, Palu. Agrotekbis, 1(2): 127-134.

[19] Salghuna, N.N., Prasad, P.R.C., Kumari, J.A. (2018). Assessing the impact of land use and land cover changes on the remnant patches of Kondapalli reserve forest of the Eastern Ghats, Andhra Pradesh, India. The Egyptian Journal of Remote Sensing and Space Science, 21(3): 419-429. https://doi.org/10.1016/j.ejrs.2018.01.005

[20] Susanti, P.D., Miardini, A., Harjadi, B. (2017). Analisis kerentanan tanah longsor sebagai dasar mitigasi di kabupaten banjarnegara (vulnerability analysis as a basic for landslide mitigation in banjarnegara regency). J. Penelit. Pengelolaan Drh. Aliran Sungai, 1(1). https://doi.org/10.20886/jppdas.2017.1.1.49-59

[21] Fashola, M.O., Ngole-Jeme, V.M., Babalola, O.O. (2016). Heavy metal pollution from gold mines: Environmental effects and bacterial strategies for resistance. Int. J. Environ. Res. Public. Health, 13(11): 1047. https://doi.org/10.3390/ijerph13111047

[22] Tuaputy, U.S. (2014). Eksternalitas pertambangan emas rakyat di kabupaten buru maluku. J. Agric. Resour. Environ. $\quad$ Econ., 1 : 71-86. http://repository.ipb.ac.id/handle/123456789/71413

[23] Attiogbe, F., Nkansah, A. (2017). The impact of mining on the water resources in ghana: Newmont case study at Birim North District (New Abirem). Energy Environ. Res., 7(2): 27. https://doi.org/10.5539/eer.v7n2p27

[24] Sonter, L.J., Ali, S.H., Watson, J.E.M. (2018). Mining and biodiversity: key issues and research needs in conservation science. Proc. R. Soc. B Biol. Sci., 285(1892). https://doi.org/10.1098/rspb.2018.1926

[25] Sutono, Haryati, U., Agus, F. (2018). Soil characteristics and rehabilitation strategies of abandoned tin-mining area in Bangka Belitung Islands Province. J. Sumberd. Lahan, 12(2): 99-116.

[26] Abeysinghe, K.S., Qiu, G.L., Goodale, E., Anderson, C.W.N., Bishop, K., Evers, D., Goodale, M.W., Hintelmann, H., Liu, S.J., Mammides, C., Quan, R.C., Wang, J., Wu, P.P., Xu, X.H.,Yang, X.D., Feng, X.B. (2017). Mercury flow through an Asian rice-based food web. Environ. Pollut., 229: 219-228. https://doi.org/10.1016/j.envpol.2017.05.067

[27] Bailey, E.A. (2002). Mercury in vegetation and soils at abandoned mercury mines in southwestern Alaska, USA. Geochem. Explor. Environ. Anal., 2(3): 275-285. https://doi.org/10.1144/1467-787302-032

[28] Cesarani, A., Minoia, C., Pigatto, P.D., Guzzi, G. (2010). Mercury, dental amalgam, and hearing loss. Int. J. Audiol., $\quad 49(1)$ : 69-70. https://doi.org/10.3109/14992020902962439

[29] Geeraert, L., Hulsmans, E., Helsen, K., Berecha, G., Aerts, R., Honnay, O. (2019). Rapid diversity and structure degradation over time through continued coffee cultivation in remnant Ethiopian Afromontane forests. Biol. Conserv., 236: 8-16. https://doi.org/10.1016/j.biocon.2019.05.014

[30] Bonsu, N.O., Dhubháin, A.N., O’Connor, D. (2019). Understanding forest resource conflicts in Ireland: A case study approach. Land Use Policy, 80: 287-297. https://doi.org/10.1016/j.landusepol.2015.11.009

[31] Handoko, C., Yumantoko, Y. (2015). Local perspectives on tenure rights and conflict in Fmu Rinjani Barat, West Nusa Tenggara Province. J. Penelit. Kehutan. Wallacea, 4(2).

https://doi.org/10.18330/jwallacea.2015.vol4iss2pp157170

[32] Yusran, Y., Sahide, M.A.K., Supratman, S., Sabar, A., Krott, M., Giessen, L. (2017). The empirical visibility of land use conflicts: From latent to manifest conflict through law enforcement in a national park in Indonesia. Land Use Policy, 62: 302-315. https://doi.org/10.1016/j.landusepol.2016.12.033

[33] Golar, G., Malik, A., Muis, H., Khairil, M., Shofirun, S., Ali, S., Razman, M.R., Awang, A. (2019). The adaptivecollaborative as a strategy communications for conflict resolution on the National Park. Ecology, Environment and Conservation, 25(4): 1836-1843. 
[34] Martínez-Espinosa, C., Wolfs, P., Valde, K.V., Satyanarayana, B., Dahdouh-Guebas, F., Hugé, J. (2020). Call for a collaborative management at Matang Mangrove Forest Reserve, Malaysia: An assessment from local stakeholders' view point. For. Ecol. Manag., 458: 117741 . https://doi.org/10.1016/j.foreco.2019.117741

[35] Ioki, K., Din, N.M., Ludwig, R., James, D., Hue, S.W., Johari, S.A., Awang, R.A., Anthony, R., Phua, N.H. (2019). Supporting forest conservation through community-based land use planning and participatory GIS - lessons from Crocker Range Park, Malaysian Borneo. J. Nat. Conserv., 52: 125740. https://doi.org/10.1016/j.jnc.2019.125740

[36] Andiko Sardi, I., Galudra, G., Warman, K. (2012). Studi kebijakan penguatan tenurial masyarakat dalam penguasaan hutan. https://lccn.loc.gov/2012330877

[37] Aguilar-Støen, M. (2018). Social forestry movements and science-policy networks: The politics of the forestry incentives program in Guatemala. Geoforum, 90: 20-26. https://doi.org/10.1016/j.geoforum.2018.01.014

[38] Anderson, N.M., Williams, K.J.H., Ford, R.M. (2013). Community perceptions of plantation forestry: The association between place meanings and social representations of a contentious rural land use. J. Environ. Psychol., $34:$

121-136. https://doi.org/10.1016/j.jenvp.2013.02.001

[39] Erbaugh, J.T. (2019). Responsibilization and social forestry in Indonesia. For. Policy Econ., 109: 102019. https://doi.org/10.1016/j.forpol.2019.102019
[40] Schaller, F.W., Sutton, P., Madison, W.I. (1976). Reclamation of drastically disturbed lands; proceedings of a symposium held 9-12 Aug 1976 at the Ohio Agricultural Research and Experiment Station, Wooster, Ohio (USA).

[41] Hermawan, B. (2011). Peningkatan kualitas lahan bekas tambang melalui revegetasi dan kesesuaiannya sebagai lahan pertanian tanaman pangan. Prosiding Seminar Nasional Budidaya Pertanian, 60-70.

[42] Li, D.D., Zhang, X.Y., Dungait, J.A.J., Green, S.M., Wen, X.F., Quine, T.A., Wang, Q.B. (2020). Main controls on the denitrification rates during cropland revegetation in the southwest China Karst Critical Zone Observatory. Agric. Ecosyst. Environ., 308: 107228. https://doi.org/10.1016/j.agee.2020.107228

[43] Opala, P.A. (2020). Influence of lime and phosphorus application rates on growth of maize in an acid soil. Advances in Agriculture, 2017. https://doi.org/10.1155/2017/7083206

[44] Trædal, L.T., Vedeld, P. (2018). Cultivating forests: The role of forest land in household livelihood adaptive strategies in the Bac Kan Province of northern Vietnam. Land Use Policy, 73: 249-258. https://doi.org/10.1016/j.landusepol.2018.02.004

[45] Golar, G., Umar, H., Rachman, I., Alam, A.S., Labir, E. (2018). The poverty assessment based on subjective criteria: Case study of rural community near protected forest in central Sulawesi. Aust. J. Basic Appl. Sci., 11(9): 22-30. 